\title{
Utility of Biodiesel in Diesel Engine
}

\author{
Md. Zahidul Islam, Nusrat Jahan Onny, Suman Chowdhury \\ Department of Electrical and Electronic Engineering, \\ International University of Business Agriculture and Technology, Dhaka-1230, Bangladesh
}

\author{
* Гorresponding Author email: \\ suman@iubat.edu \\ Article Histary \\ Received: 22 November 2019 \\ Revised: 12 December 2019 \\ Accepted: 28 February 2020 \\ Published: 06 March 2020 \\ Student(s) \\ - Md. Zahidul Islam \\ - Nusrat Jahan Onny \\ Academic Year: 2019-20 \\ Course Level: Bachelor \\ Course Name: B.Sc. \\ Course year: Final Year
}

\begin{abstract}
The energy resources from the fossil fuels are decreasing day by day. Rather fossil fuel is costly, it creates environmental problems by producing $\mathrm{SO}_{\mathrm{x}}$ and $\mathrm{NO}_{\mathrm{x}}$ in the environment. Now it is argent to find a solution. The solution can be renewable energy. In this paper the effort was to find the utility of biodiesels in the conventional diesel engine. This biofuel or biodiesel is extracted from Soybean methyl ester (SME). We compared the basic performance characteristics diesel, SME 20 and SME 100 in unmodified diesel engine. This experiment will be helpful to find out the utility of SME type biodiesel in conventional diesel engine so that the uses of fossil fuels can be reduced in quick rental power plants and other uses. We can use biodiesel as substitute in an economic tariff and efficient way.
\end{abstract}

Keywords: Biodiesel, Soybean methyl ester (SME), diesel 2, pure diesel, B20 SME, B100 SME, diesel engine, performance.

\section{Introduction}

For fulfilling the demand for industrial development, agriculture sector, transportation etc petroleum fuels plays a vital role. Due to excessive usage, these fuel reserves are fast depleting. Besides so many problems associated with crude oil like $\mathrm{CO}_{2}, \mathrm{HC}, \mathrm{NO}_{x}$, and $\mathrm{SO}_{\mathrm{x}}$ are being a regular exerciseby researchers [1]. In recent times, biodiesel has received significant focus both as a possible renewable fuel alternative and as an additive to the existing petroleum based fuels [2]. Biodiesel is a non-toxic, biodegradable and renewable fuel alternative so that it can be used without any engine modifications. It can be extracted from various vegetables, waste cooking oils or animal fats. The properties of Biodiesel may vary when different feed stocks are used. In general, if the fuel properties of Biodiesel are compared to petroleum diesel fuel, it can be seen that biodiesel has a higher viscosity, density, and cetane number. But the conventional diesel fuelhas10-12 $\%$ higher energy content or net calorific value than biodiesel on the mass [3]. Through the simulation techniques, the fast development of computer technology narrows down the time consumption for engine test. The insight of the combustion process is analyzed thoroughly, which increase the engine power output and consider as the heart of the engine process [4-6].

The objectives of the research are to find the utility of biodiesel in diesel engine, however the objectives of this research include the utility of SME 20 and SME 100 biodiesels, the characteristics and performances of 
the SME 20 and SME 100 biodiesels, comparison between Diesel 2, SME 20 and SME 100 using a software named Diesel-rk software.

A lot of research works need to be done on probability of biodiesel to replace the diesel fossil fuel in agricultural uses to power plant. Specifically works can be done on which biodiesel blend is more efficient. Our results show the possibility, but research should be done to increase the efficiency of the biodiesel so that the biodiesel can be a better alternative to fossil fuel. There is a huge potentiality of biodiesel. If biodiesel replaces the petroleum fuel then that will be a huge change in political, socioeconomic and environment situation. That will create a significant impact on energy prices worldwide. The negative environmental consequences of fossil fuel combustion will reduce largely. Reliable, economic and safe fuel for power generation to meet up the power scarcity will be available will be available.The future work includes to find the potentiality of the biodiesel blends to implement them in the diesel engine of diesel power plant to generate power.

Mohamed F. Al-Dawody and S. K. Bhatti's (2013) research paper "Theoretical modeling of combustion characteristics and performance parameters of biodiesel in DI diesel engine with variable compression ratio" shows a mathematical model which was developed using a quick basic computer program (Diesel rk software) for analyzing the combustion and performance characteristics in diesel engine with variable compression ratio. Their findings predicted the engine performance characteristics in close approximation to that of obtained by the performance characteristics of diesel [23].

Chang et al. used a four-cylinder turbocharged DI diesel engine fueled with blends of methyl and isopropyl esters of soybean oil in No. 2 diesel fuel to test the engine's performance and emissions. The results indicated that engine performance for all the fuel blends was similar to No. 2 diesel fuel. The CO emissions of all fuel blends were significantly lower than for No. 2 diesel fuel [24].

In 2011, Mohamed F. Al-Dawody and S. K. Bhatti showed the effects of SME and its blends as an alternative source of energy on the performance and emissions of diesel engine by using the Diesel-RK software. They Used the SME and its blends to reduce the thermal efficiency, power, and SFC as compared to pure diesel fuel. Reductions in the emissions made SME and its blends a suitable alternative fuel for diesel and thus could be ecofriendly [7].

Scholl and Sorenson fueled a direct injection diesel engine with soybean oil methyl ester and diesel fuel to investigate the combustion of the methyl ester. The results indicated that the soybean oil methyl ester behaved comparably to diesel fuel in terms of performance and rate of heat release. Lower HC emissions and smoke number were found for the methyl ester. The $\mathrm{CO}$ emissions results were mixed. The NOx, emissions were strongly related to the cylinder pressure. The variation of injection timing had a pronounced effect on performance and emissions for both fuels.[25]

Indraj Singh, find on their paper "Electric Power Generation Using Jatropha Biodiesel and Its Blend as Fuel in CI Engine for Rural Area" that, the fuel properties of jatropha biodiesel, such as, specific gravity and calorific value were found within the limits of BIS standard. In the case of jatropha biodiesel B-25 overall efficiency was found at maximum than petro diesel fueled electric generator driven by compression ignition engine due to complete combustion and reduction in the calorific value of the fuel. Electricity can be generated by using blended biodiesel fuel B25 using in electric generator coupled with compression ignition engine without sacrificing the power output especially for rural area [26].

\section{Physical properties of fuels}

Properties like density, viscosity, flash point, cetane number, lower heating value of the diesel and Soybean methyl ester (SME) biodiesel are presented as the properties are necessary as input data for the calculation of combustion parameters and heat release rates. Table 1 presents the properties of diesel fuel and both biodiesel (SME)B20 and B100. The theoretical analysis was done on a naturally aspirated, water cooled, four stroke, single cylinder, direct injection diesel engine. The specifications of the engine are shown in Table 2. 
Islam et al., Adv. J. Grad. Res.; Vol. 8, Issue 1, pp: 8-17, July 2020

Table 1: Properties of diesel fuel and SME biodiesel [7]

\begin{tabular}{|l|l|l|l|}
\hline Properties & Diesel & B20 & B100 \\
\hline Density [kg/m3] & 830 & 841 & 876 \\
\hline Viscosity [Pa.s] & 0.003 & 0.00334 & 0.00463 \\
\hline Flash point [Co] & 55 & 80 & 170 \\
\hline Cetane number & 48 & 48.69 & 51.3 \\
\hline $\begin{array}{l}\text { Lower heating value } \\
{[\mathrm{MJ} / \mathrm{kg}]}\end{array}$ & 42.5 & 41.18 & 36.22 \\
\hline
\end{tabular}

Table 2: Specification of engine [7]

\begin{tabular}{|l|l|}
\hline Engine Make & Kirloskar AV-1 \\
\hline Engine Type & $(4-$ Stroke, Diesel Engine $)$ \\
\hline Number of Cylinder & 1 \\
\hline Bore $\times$ stroke & $87.5 \times 110 \mathrm{~mm}$ \\
\hline Cylinder capacity & $0.66 \mathrm{~L}$ \\
\hline Compression ratio Variable & $(12-19)$ \\
\hline Rated power & $3.7 \mathrm{~kW}, 1500 \mathrm{rpm}$ \\
\hline Dynamometer & Electric AC-generator \\
\hline Orifice diameter & $0.15 \mathrm{~mm}$ \\
\hline Injection pressure & $(200-220)$ bar \\
\hline
\end{tabular}

\subsection{Biodiesel}

Soybean Biodiesel, is made from vegetable oil reacted with methanol and a catalyst, yielding biodiesel (fatty acid methyl esters) and glycerin as a by-product. It can be used in any diesel engine without any modifications and can be substituted for petroleum-diesel fuel in diesel engines, as there is a need for alternative fuel sources, which is biodegradable, economical to produce, eco-friendly to use due to the depletion of the world petroleum reserves, increase in global warming and environmental concerns (22).

\section{Methodology}

Diesel-rk simulation software was used to find the result. For computation and improvement of internal combustion of diesel engine Diesel rk software has been introduced. It has advanced model of mixture formation and combustion in a diesel engine and also the tool for multi parameter optimization. Same operating conditions and fuel properties with engine specifications were used as input data to the software.

\section{Theoretical analysis}

The present work involves the using of diesel, (SME) B20 and B100biodiesel fuels in a diesel engine with variable compression ratio (12-19). The simulation results are then used to compare with the results computed in the Diesel-rk simulation software. In this analysis the molecular formula for diesel and biodiesel are approximate, as $\mathrm{C}_{13.77} \mathrm{H}_{23.44}$ and $\mathrm{C}_{19} \mathrm{H}_{35} \mathrm{O}_{2}$ respectively [8, 9]. The C.I. engine with any hydrocarbon fuels is compatible with developed combustion model. Different species of the moles are considered includes $\mathrm{O}_{2}, \mathrm{~N}_{2}$ from the intake air and $\mathrm{CO}_{2}$ and $\mathrm{H}_{2} \mathrm{O}$ from the residual gases, at the time of combustion to be started. The performance equation for the fuel with $\mathrm{C}-\mathrm{H}-\mathrm{O}-\mathrm{N}$ is:

$$
(1-\lambda) C_{n 1} H_{m 1}+\lambda . C_{n 2} H_{m 2} O_{z}+X\left[O_{2}+3.76 N_{2}\right] \rightarrow{ }_{V} C_{2} O_{2}+V_{2} H_{2} O+V_{3} N_{2}+V_{4}(1)
$$

Where, the mole ratio of biodiesel, $\lambda$ added $n_{1}, m_{1}$ number of carbon and hydrogen atoms for diesel fuel respectively, $\mathrm{n}_{2}, \mathrm{~m}_{2}, \mathrm{z}$ the number of carbon, hydrogen and oxygen for biodiesel fuel respectively, $v$ mole fraction of product species, $\mathrm{X}$ number of kmoles of oxygen per one kmole of fuel and its equal to: 


$$
X=\left(\frac{1}{\phi}\right) *\left[n_{1}(1-\lambda)+n_{2} \lambda\right]+\frac{\left.m_{1}(1-\lambda)+m_{2} \lambda\right]}{4}-0.5 z . \lambda
$$

Where, $\phi$ is equivalence ratio. The number of reactants and products used during the start of combustion as well as every degree crank angle can be found from the equations:

$N_{r}=1+X * 4.76(3)$

$N_{p}=\left(\lambda . n_{1}+(1-\lambda) n_{2}\right)+0.5 *\left(\lambda . m_{1}+(1-\lambda) m_{2}\right)+3.76 * X+(\phi-1) *\left[n_{1}(1-\lambda)+\right.$ $\left.n_{2} \lambda\right]+\frac{\left[m_{1}(1-\lambda)+m_{2 \lambda}\right]}{4}-0.5 z . \lambda$

\subsection{Volume of cylinder}

The cylinder volume at any crank angle is given by [10]:

$$
\mathrm{V}(\theta)=\mathrm{v}_{\text {disp }}\left[\frac{\varepsilon}{\varepsilon-1}-\frac{1-\cos (\theta)}{2}+\frac{\mathrm{L}}{\mathrm{S}}-0.5 \sqrt{\left(\frac{2 \mathrm{~L}}{\mathrm{~s}}\right)^{2}-\operatorname{SIN}^{2}(\theta)}\right]
$$

whereV $\mathrm{V}_{\text {displacement }}$ volume $\left(\mathrm{m}^{3}\right), \varepsilon$ compression ratio, $\mathrm{L}$ connection rod length $(\mathrm{m}), \mathrm{S}$ stroke $(\mathrm{m})$

\subsection{Calculation of specific heat}

At constant volume and constant pressure, the specific heat for each species is in $\mathrm{kJ} / \mathrm{kg} . \mathrm{K}$ and can be found using the expression given below [9]:

$C_{v}(T)=C_{p}(T)-R(6)$

$C_{p}(T)=b+\frac{c}{T}(7)$

where $\mathrm{b}$ and $\mathrm{c}$ are the coefficients of polynomial equation and $\mathrm{R}$ is gas constant $(\mathrm{kJ} / \mathrm{kg} . \mathrm{K})$.

\subsection{Pressure and temperature during compression}

The pressure and temperature for the compression process at the beginning time is provided as follows;

$$
\begin{array}{r}
P_{2}=\left(\frac{V_{1}}{V_{2}}\right) *\left(\frac{T_{1}}{T_{2}}\right)(8) \\
T_{2}=T_{1} * R / \varepsilon^{\left(C_{v}\left(T_{1}\right)\right)}
\end{array}
$$

\subsection{Calculation of enthalpy and internal energy}

Enthalpy of each species is calculated from the expression given below which is used to calculate the peak flame temperature of the cyclic process.

$$
H(T)=a+b * T+c * \ln (T)(10)
$$

The internal energy for each species and overall internal energy are calculated from the expressions given below [10]:

$$
\begin{gathered}
U(T)=a+(b-R) * T+c * \ln (T)(11) \\
U(T)=\sum\left(X_{1} U_{1}(T)\right)(12)
\end{gathered}
$$

where $a, b, c$ are the coefficients of polynomial equation.

\subsection{Heat transfer model}

Woschni heat transfer model can be preferred for finding out gas wall heat transfer equation. [11].

$\frac{d \varphi_{h t}}{d t}=h_{c} A_{c}\left(T_{g}-T_{w}\right)$

where $h_{c}$ heat transfer coefficient $\left(\mathrm{w} / \mathrm{m}_{2} \mathrm{~K}\right)$, Ac convection heat transfer area $(\mathrm{m} 2), T_{g} \& T_{w}$ gas and wall temperature respectively $\left(k^{\circ}\right)$ For convection Woschni developed the following empirical correlations for Nusselt number; 
$N_{u s}=0.035 R_{e^{0.8}}(14)$

where Reis Reynolds number which is given by;

$R_{e}=\rho w B / \mu_{p}$

where B cylinder bore (m), $\mu_{p}$, kinematic viscosity (Pa. s). The above correlation can be rewritten;

$h_{c}=3.26 B^{-0.2} T^{-0.55} P^{0.8} W^{0.8}$

During the compression process, Woschni argued that the average gas velocity should be proportional to the mean piston speed. During combustion and expansion processes he attempted to account directly for the gas velocities induced by the change in density that results from combustion. The following expression is used;

$W=\left[C_{1} u_{p}+C_{2}\left(\frac{v_{\text {disp }}}{v_{c y l}}\right)\left(\frac{p(\theta)-p_{\text {motor }}(\theta)}{p_{c y l}}\right)\right] T(17)$

Where $\mathrm{C}_{1}$ and $\mathrm{C}_{2}$ are model constant,

For gas exchange period: $\mathrm{C}_{1}=6.18 ; \mathrm{C}_{2}=0$

For compression period: $\mathrm{C}_{1}=2.28 ; \mathrm{C}_{2}=0$

For the combustion and expansion period: $\mathrm{C}_{1}=6.18 ; \mathrm{C}_{2}=3.24 * 10-3$

$\mathrm{u}_{\mathrm{p}}$ average piston speed $(\mathrm{m} / \mathrm{s}), \mathrm{p}_{\text {cyl }}$ pressure of cylinder at initial condition (bar).

\subsection{Energy equation according to the first law of thermodynamics the energy balance equation is given by}

$U\left(T_{2}\right)=U\left(T_{1}\right)-d W-d Q_{h t}+d m_{f} Q_{m}(18)$

where in $\mathrm{Q}$ total heat supply $(\mathrm{kJ} / \mathrm{kg})$. Both sides of the above equation need to be balanced finding out correct value of $\mathrm{T}_{2}$. So the above equation is rearranged as shown below;

$E R R_{1}=U\left(T_{1}\right)-U\left(T_{2}\right)-d W-d Q_{h t}+d m_{f} d Q_{m}(19)$

If the numerical value $E R R_{1}$ is less than the accuracy required, then the correct value of $T_{2}$ has been established, otherwise a new value of $\mathrm{T}_{2}$ is calculated for new internal energy and $C_{v}$ values.

$E R R_{2}=C_{v}\left(T_{2}\right) * N_{p}(20)$

Using Newton Raphson method to get;

$\left(T_{2}\right)=\left(T_{2}\right)_{n-1}-E R R_{1} / E R R_{2}(21)$

\subsection{Combustion model}

Due to hurdle combustion process of fuel and air, extensive modeling is needed to fulfill the requirement. In this work Wiebe function is used which some time is spelled Wiebe function to simulate the combustion process [12]. The Wiebe function is often used as a parameterization of the mass fraction burned and it has the following form;

$X_{b}(\theta)=1-e^{-a\left(\frac{\theta-\theta_{i g}}{\Delta \theta}\right)^{m+1}}$ 
And the differential equation for the burn rate is given as follows:

$\frac{d x_{b}(\theta)}{d \theta}=\frac{a(m+1)}{\Delta \theta} \cdot\left(\frac{\theta-\theta_{i g}}{\Delta \theta}\right)^{m} \cdot e^{-a\left(\frac{\theta-\theta_{i g}}{\Delta \theta}\right)^{m+1}}$

where $\mathrm{a}$ is a parameter which characterizes the completeness of combustion and its equal to $6.908, \mathrm{~m}$ is a parameter characterizing the rate of combustion. The small value of $\mathrm{m}$ means a high rate at the beginning of combustion, while a large value of $\mathrm{m}$ means a high rate by the end of combustion, $\theta_{i g}$ crank angle at which combustion starts (degrees) and $\Delta \theta$ total combustion duration (degrees). The absolute value of the heat release rate is given by the fuel mass $\mathrm{mf}$, the heating value of fuel and combustion efficiency $\eta_{c}$ as [12];

$\frac{d Q_{c h}}{d \theta}=m_{f} \cdot q_{H V} \cdot \eta_{c} \cdot d x_{b} / d \theta$

\subsection{Two-zone mean temperature model}

A two-zone model is divided into two zones; one containing the unburned gases, and the other containing the burned gases separated by the flame front. Prior to start of combustion (SOC), the unburned zone temperature $T_{u}$ equals to the single zone temperature. The unburned zone temperature after the start of combustion is then computed assuming adiabatic compression of the unburned charge according to:

$T_{u}=T_{\text {soc }}\left(\frac{p}{p_{\text {soc }}}\right)^{\frac{\gamma-1}{\gamma}}(25)$

where $T_{\text {soc }} \& P_{\text {Soc }}$ temperature and pressure at the start of combustion respectively. The energy balance between single-zone and two-zone model yields:

$\left(m_{b}+m_{u}\right) C_{v} T=m_{b} C_{v} T+m_{u} C_{v} T_{u}(26)$

Assuming $C_{v}=C_{v_{b}}=C_{v_{u}}$ a calorically perfect gas, end up in:

$T=\frac{m_{b} T_{b}+m_{u} T_{u}}{m_{b}+m_{u}}=x^{b} T_{b}+\left(1-x_{b}\right) \cdot T_{u}(27)$

where the single zone temperature $\mathrm{T}$ which is found from the equation of state can be used as the mass weighted mean temperature of the two zones [12]. From equation (26) we can calculate the burned zone temperature;

$T_{b}=\frac{T-\left(1-X_{b}\right) T_{b}}{X_{b}}(28)$

\subsection{Diesel-rk simulation software}

The software Diesel-rk is used to check the performance of internal combustion engines with bio diesel. It has advanced RK model of mixture formation and combustion in a diesel engine, and also the tool for multi parameter optimization [13]. Same operating conditions and fuel properties with engine specifications were used as input data to the software. The details of the computed results are mentioned in [7,14]. Authors and Affiliations

\subsection{Results and discussions}

Combustion parameter like combustion zone temperature, peak cylinder pressure, cylinder pressure, and ignition delay and heat release are talked in this study. Performance parameters like brake power, and brake specific fuel consumption are analyzed with variable compression ratio from 12 to 19 where the engine speed is constant about $1500 \mathrm{rpm}$ and $20^{\circ}$ BTDC injection timing. 


\section{Simulation}

\subsection{Cylinder pressure}

During the premixed burningphase the cylinder pressure is dependent on the fuel burning rate, in a CI engine. High cylinder pressure is required to ensure better combustion and heat release. For diesel and biodieselFigure 1, shows the pressure variation with respect to crank angle respectively as compareddiesel-rk Simulation. It can be seen that cylinder pressure for biodiesel SME 20 is lower than that of diesel by $5 \%$ and for biodiesel SME 100 it is lower than $10 \%$ asthe heat supply is reduced for the blended fuel. Maximum pressure obtained for biodiesel is closer to top dead center than diesel fuel. For both diesel andbiodiesel the pressure of cylinderconcludes into an agreement with the results found by Diesel-rk software [7].

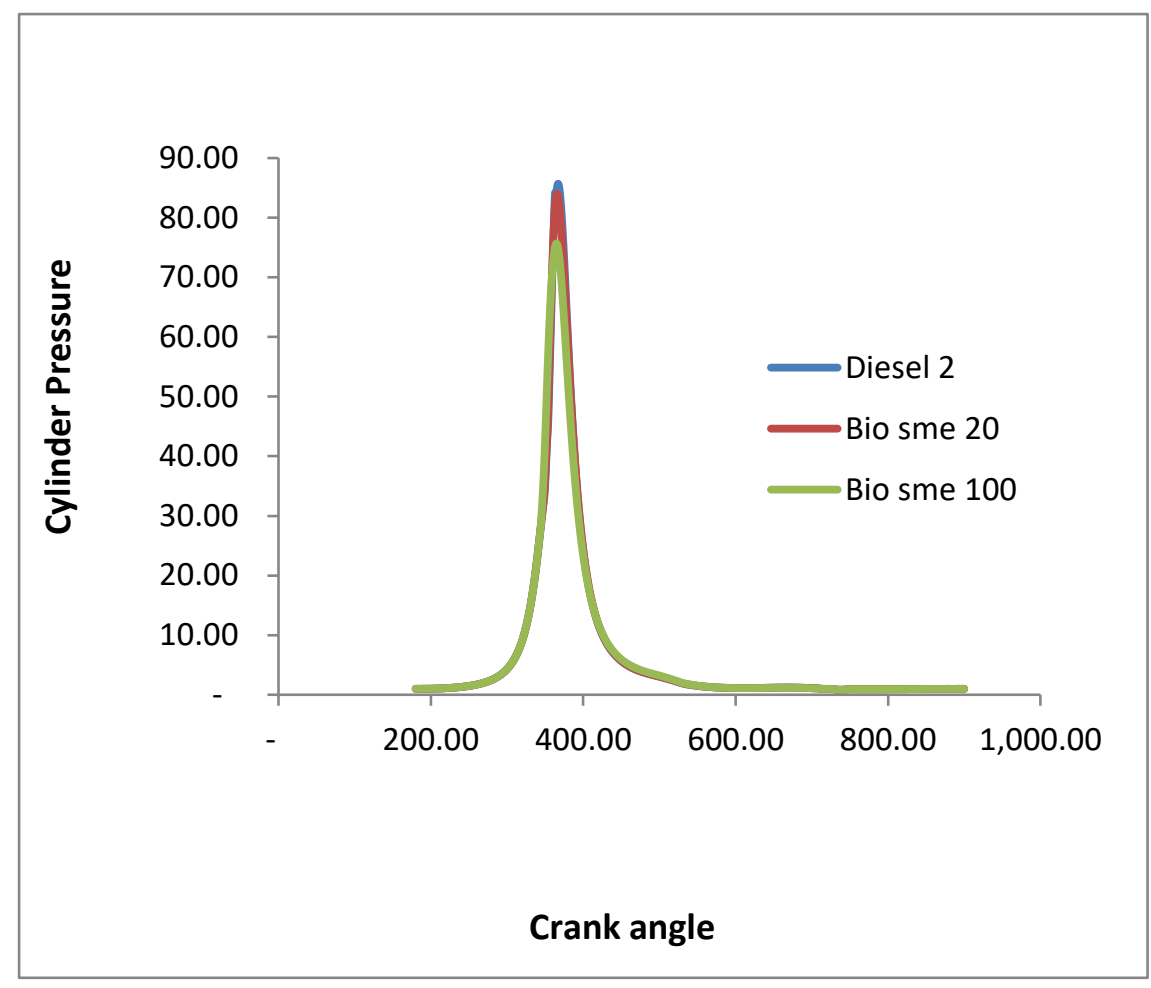

Figure 1: Crank angle versus cylinder pressure.

\subsection{Zonal combustion temperature}

Figure 2 explains the comparison between combustion zone temperature with crank angle for diesel and biodiesel. Biodiesel does complete combustion of fuel by generating more $\mathrm{CO} 2$ as a result more heat is released from the gases because of the presence of oxygen in it [15, 16]. Thus, the biodieselfueled engine has higher peak temperature than that of diesel fueled engine by $1.5 \%$. Results for both fuels are verified with computed in Diesel-rk at the same operating conditions.

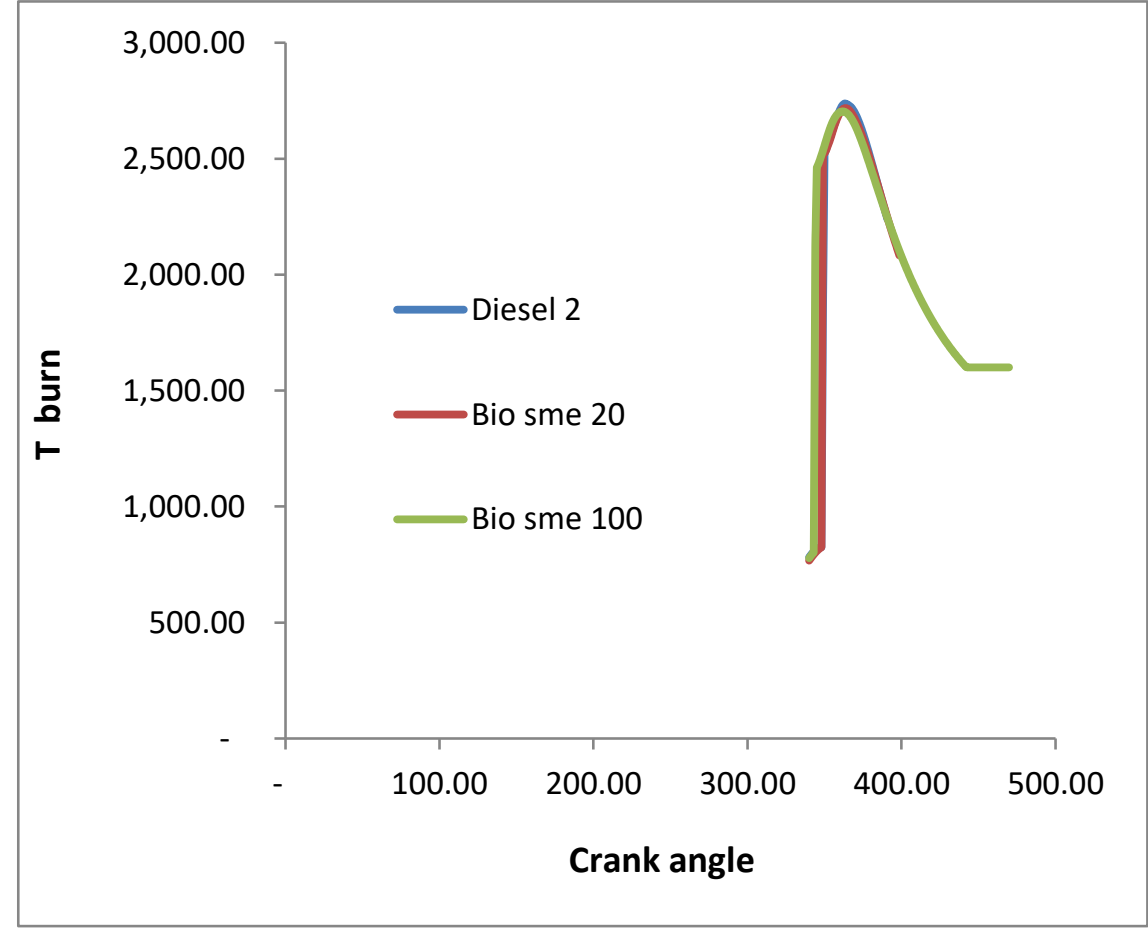

Figure 2: Crank angle versus Combustion zone temperature. 


\subsection{Heat release rate}

Computed heat release fraction for diesel fuel, B20 and B100 SME are presented byFigure 3. Hence, an earlier start of combustioncan happen by biodiesel blend but having a slower combustion rate is proved. The earlier start of injectionand shorter ignition delay causes the early start of combustion; and the slower premixed combustion rate because of less energy released in premixed phase and also the lower volatility of biodiesel. The SME biodiesel fuels had rapid combustion as atthe diffusion combustion phase point most of fuels get vaporized. Both fuels show the same behavior like the computed results in Diesel-rk software.

\subsection{Maximum pressure}

In Figure 4, for both diesel and biodieselthe effect of compression ratio on the maximum pressure is presented. It is showed that maximum pressure rises with the increase in compression ratio because of the rise in the rate of heat release. The maximum pressure for diesel is higher than the maximum pressure of biodiesel by $1.76 \%$, while it's come up with $1.48 \%$ in the results of Dieselrk for SME B20.

\subsection{Ignition delay}

Between the start of combustion and start of injection, the delay period can be represented as the time difference. The ignition delay period can be affected by the physical and chemical properties of the fuels and researchers have proved that the chemical properties are much more important than the physical properties [17]. Usually cetane number characterizes the ignition quality of a fuel. A higher cetane number generally defines the shorter ignition delay. So, blends of SME biodiesel cause shorter ignition delay which causes earlier start of combustion, and the amount of energy released is less in premixed phase. The same results were reported by [18]. It can be observed from Figure 5 that ignition delay for B20 SME is lower than diesel fuel by $17.6 \%$ whereas ignition delay of $\mathrm{B} 100 \mathrm{SME}$ is much less than the B20 SME.

\section{Compression ratio vs HRF}

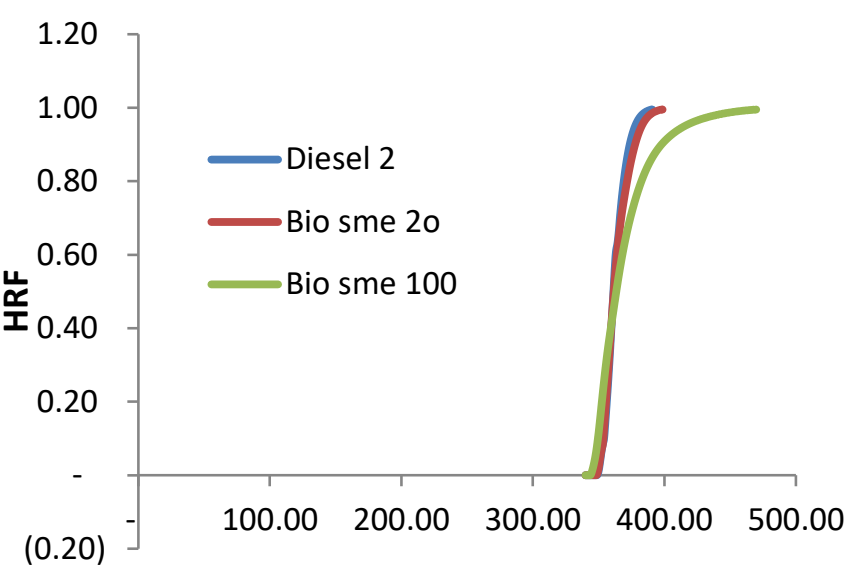

Compression ratio

Figure 3: Crank angle versus Heat release fraction.

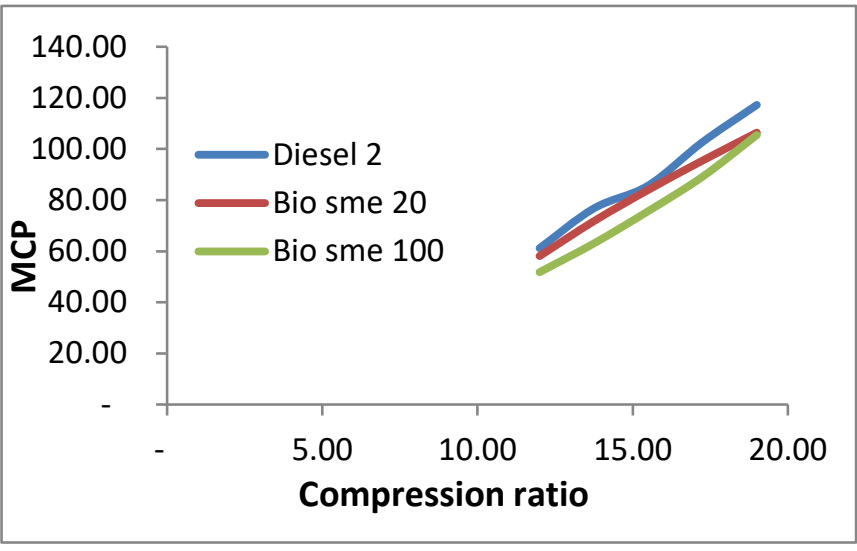

Figure 4: Compression ratio versus maximum cylinder pressure.

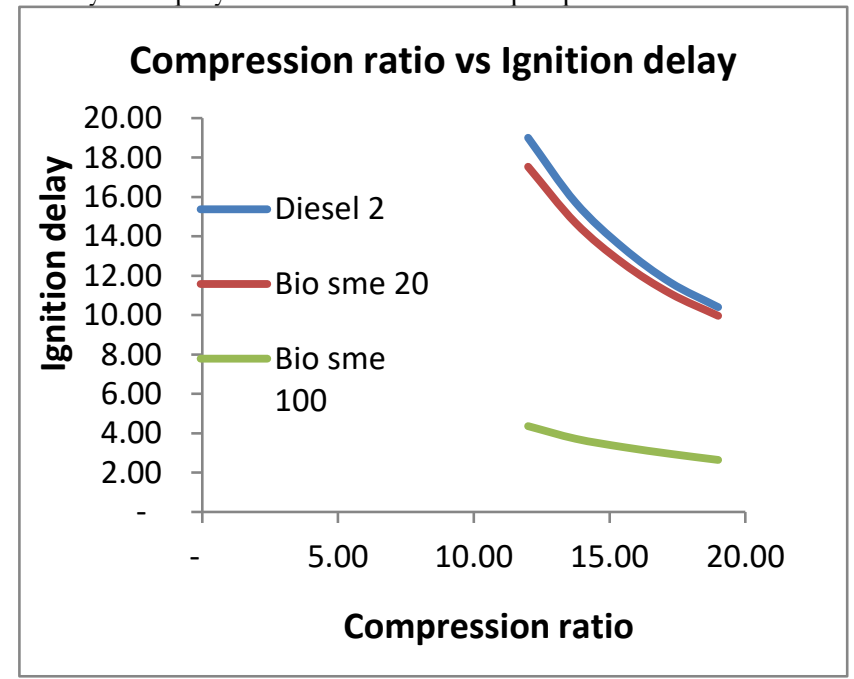

Figure 5: Compression ratio versus Ignition delay. 


\subsection{Brake Specific fuel consumption (BSFC)}

The variation of BSFC with pure diesel, 20\% SME and 100\% SME biodiesel with changed compression ratios are presented in Figure6 respectively, as the compression ratio rising there is a negative impact of decreasing in the engine power due to an increase in the load and thermal stresses on the engine, which causes an increase in the SFC. 3\% more engine power is obtained by pure diesel than the B20 SME. This is becsause of lower heating value of biodiesel fuel compared to diesel fuel. On the other hand, the SFC, in general, was found to increase with the rising proportion of biodiesel in the fuels. BSFC for all SME blending fuels including B20 and B100is higher than pure diesel fuel. B20 fuel is higher than diesel 2 by $12 \%$ because of the presence of oxygen in its molecule. The increase in SFC is because oflower heating value andhigher density, as the heating valuesof methyl esters are about $12.4 \%$ less than diesel 2 (pure Diesel). These results are similar to those of Monyem A. [19] \&Canakci M. [20] \& Mustafa Canakci and Jon H. Van Gerpen [21]. The Diesel-rk results are used to verify the simulation results.

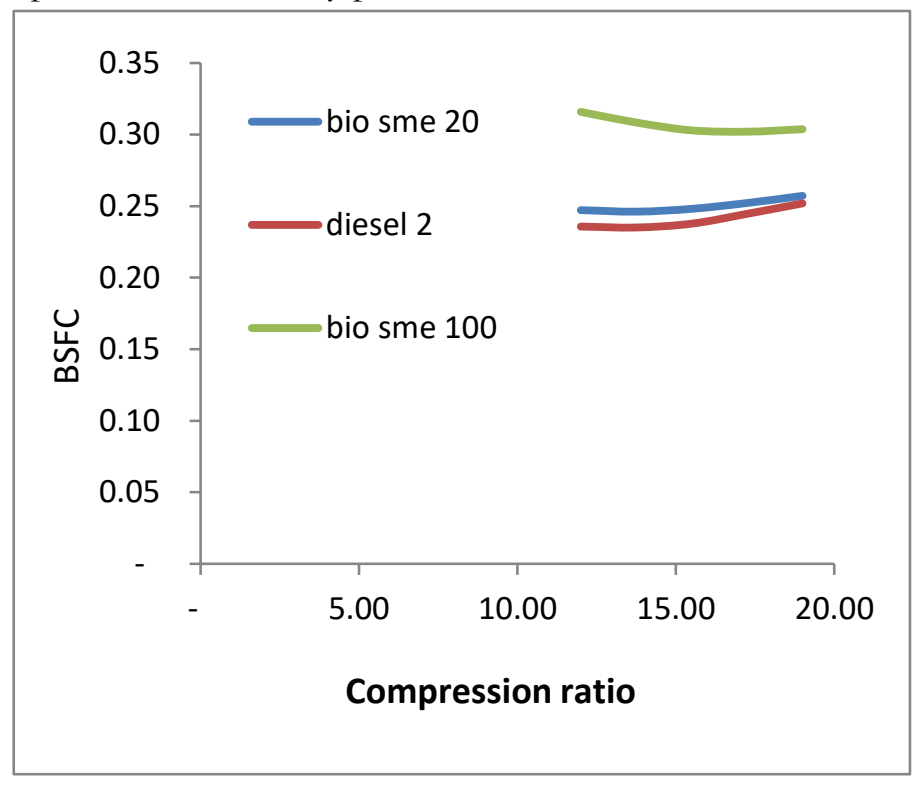

Figure 6: Compression ratio versus Specific fuel consumption

\section{Conclusion}

From the performance characteristics, simulation results and Diesel-rk results, it is proved that biodiesel can be an alternative to convenient diesel fossil fuel. The above performances show the almost similar curves for the biodiesel SME blends B20, B100 and diesel. In case of heat release rate, the biodiesel blend had slower combustion rate but an earlier start of combustion. The earlier start of injection causes the early start of combustion. Earlier start of combustion occurs due to shorter ignition delay produced by SME biodiesel blends. BSFC for B20 SME and B100 SME fuels is higher than diesel 2 (pure Diesel) by $12 \%$ because of the presence of oxygen in its molecule.

\section{Declarations}

\subsection{Acknowledgements}

We are heartily grateful to Prof. Dr. Bishwajit Saha coordinator of EEE department for his valuable support.

\subsection{Competing Interests}

We the authors declare that there is no conflict of interest exists in this work.

\section{How to Cite this Article:}

M. Z. Islam, N. Onny, and S. Chowdhury, "Utility of Biodiesel in Diesel Engine", Adv. J. Grad. Res., vol. 8, no. 1, pp. 817, Mar. 2020. doi: 10.21467/ajgr.8.1.8-17

\section{References}

[1] Sunil Kumar, A. ChaubeS.Kumar "Experimental evaluation of C.I. engine performance using diesel blended with Jatropha biodiesel”, international journal of energy and environment volume 3, issue 3, 2012 pp.471-484.

[2] B. Gokalp, E. Buyukkaya, H.S. Soyhan, 'Performance and emissions of a diesel tractor engine fueled with marine diesel and soybean methyl ester’, International journal of biomass and bioenergy, (2011), 3575-3583. 
[3] CengizOner and SehmusAltun, "Biodiesel production from inedible animal tallow and an experimental investigation of its use as alternative fuel in a direct injection diesel engine", journal of applied energy, 2009.

[4] B.RajendraP.Tamilporai, Mohd.F.Shabir, "Simulation and Analysis of Combustion Performance and Emission Characteristics of Biodiesel Fueled Low Heat Rejection Direct Injection Diesel Engine”, SAE Paper No. 2007-32-0094.

[5] Mohd.F.Shabir, Tamilporai P., and RajendraPrasath, "Analysis of Combustion, Performance and Emission Characteristics of Turbocharged LHR Extended Expansion DI Diesel Engine’, International Journal of Mechanical Systems Science and Engineering, Vol. 2, No. 2, pp. 126-137, 2010.

[6] V. Ganesan, “Computer simulation of compression ignition engines”, University Press (India) Ltd.; 2000.

[7] Mohamed F. Al-Dawody, S.K. Bhatti, Effect of soybean oil biofuel blending on the performance and emissions of diesel engine using diesel-rk software, International journal of engineering science and technology, 4539-4555, (2011).

[8] A.S. Ramadhas_, S. Jayaraj, C. Muraleedharan, "Theoretical modeling and experimental studies on biodiesel-fueled engine", Renewable Energy 31, 1813-1826. 2006.

[9] B. Rajendra, P. Tamil ,Mohd. F. Shabir,' Two-zone modeling of diesel/biodiesel blended fuel operated ceramic coated direct injection diesel engine', International journal of energy and environment, volume 1, Issue 6, pp.1039-1056, 2010.

[10] J.B. Heywood, "Internal combustion engines fundamentals", Tata McGraw Hill Book Company; 1989.

[11] Woschni, G., "A Universally Applicable Equation for the Instantaneous Heat Transfer Coefficient in the Internal Combustion Engine", SAE Paper No.670931, 1967.

[12] Marcus K.,' A specific heat ratio model and compression ratio estimation', Linkoping studies in science and technology, thesis no.1104, 2004.

[13] Http://www.diesel-rk.bmstu.ru.

[14] Mohamed F. Al-Dawody, S.K. Bhatti, 'Simulation and optimazation study for the reduction of Nox emissions of diesel engine working with soybean oil biofuel blendings using diesel-rk software',27th national convention of chemical engineering, September 30 - October 01, 2011.

[15] A. N. Ozsezen, M. Canakci, 'Determination of performance and combustion characteristics of a dieselengine fueled with canola and waste palm oil methyl esters', Int. journal of Energy Conversion and Management, volume.52, 108-116, (2011).

[16] D.Tamilvendhan "performance, emission and combustion characteristics of a methyl ester sunflower oil eucalyptus oil in a single cylinder air cooled and direct injection diesel engine", International Journal of Engineering Science and Technology, Vol. 3 No. 3 March 2011.

[17] V.Ganesan,'Internal combustion Engines', published by Tata McGraw hill education privatelimited, 2007.

[18] W. Yuan, A. Hansen, 'Computational investigation of the effect of biodiesel fuel properties ondiesel engine NOx emissions', Int J Agric\&BiolEng, June,2009.

[19] Monyem, A."The effect of biodiesel oxidation on engine performance and emissions". Ph.D. Dissertation, Department of Mechanical Engineering, Iowa State University, Ames, IA, 1998.

[20] Canakci M. 'Combustion characteristics of a turbocharged DI compression ignition engine fueledwith petroleum diesel fuels and biodiesel". Bioresour Technol;98:1167-75.,2007.

[21] Mustafa Canakci and Jon H. Van Gerpen, "Comparison of Engine Performance and Emissions forPetroleum Diesel Fuel, Yellow Grease Biodiesel, and Soybean Oil Biodiesel", Presented as Paper No. 016050 at the 2001 ASAE California, USA July 30-August $1,2001$.

[22] METHYL-ESTER SOYBEAN OIL: BIODIESEL GopiUttarakavatam, Balaji G, Bholu Kumar, ChhotaBabu, Ravi Chandra Ganesh P,Vol.02 No.01, April 2012.

[23] Mohamed F. Al-Dawody, S. K. Bhatti, "Theoretical modeling of combustion characteristics and performance parameters of biodiesel in DI diesel engine with variable compression ratio", International Journal of Energy \& Environment, 2013, Vol. 4 Issue 2, p231-242.

[24] Chang. Y. Z. D. Van Gerpen. J.H. Lee. I. Johnson. L.A. Hammond. E.G. and Marley. S.J. Fuel Properties and Emissions of Soybean Oil Esters as Diesel Fuel .J. AOC'S. vol. 73. No. 11. 1996. pp. 1549-1555with variable compression ratio, Volume 4, Issue 2, 2013 pp.231-242.

[25] Scholl. K.W., Sorenson. S.C. Combustion of Soybean Oil Methyl Ester in a Direct Injection Diesel Engine. SAE paper 930934.1993 [26] Indraj Singh, V.Sahni, "Electric Power Generation Using Jatropha Biodiesel and Its Blend as Fuel in CI Engine for Rural Area", Annual Conference on Life Science and Engineering, At OSAKA, JAPAN.

Publish your books with AIJR publisher-

- Publish with ISBN and DOI.

- Publish Thesis/Dissertation as Monograph.

- Publish Book Monograph.

- Publish Edited Volume/ Book.

- Publish Conference Proceedings

- Retain full copyright of your books.

Submit your manuscript at books.aijr.org
Publish your research article in AIJR journals-

- Online Submission and Tracking

- Peer-Reviewed

- Rapid decision

- Immediate Publication after acceptance

- Articles freely available online

- Retain full copyright of your article. Submit your article at journals.aijr.in 